\title{
The Co-Construction of Interculturality Through an Ecological Perspective in Teletandem Activities ${ }^{1}$
}

\section{A co-construção da interculturalidade a partir de uma perspectiva ecológica em atividades do teletandem}

Rodrigo Schaefer*

*Instituto Federal Catarinense (IFC), Campus Brusque, Brusque, Santa Catarina /Brasil rodrigo.schaefer@ifc.edu.br

https://orcid.org/0000-0002-2349-0175

\begin{abstract}
Telecollaboration involves the use of online technologies in the context of language teaching and learning (O'DOWD, 2013). This study sought to understand how the co-construction of interculturality took place in a specific telecollaborative context - teletandem (TELLES; VASSALLO, 2006; TELLES, 2015a, 2015b). For the analysis, data from a teletandem session, a mediation session, an experience report and an interview were included. From an ecological perspective (VAN LIER, 2004; KRAMSCH; STEFFENSEN, 2008), the outcomes showed that the co-construction of interculturality was a process, that is, it occurred over time and through different instances. Put differently, instances subsequent to the teletandem session, e.g. the mediation session and the experience report, were essential for this co-construction.
\end{abstract}

KEYWORDS: interculturality; teletandem; telecollaboration; online intercultural exchange; online teaching and learning of foreign languages.

RESUMO: A telecolaboração envolve o uso de tecnologias online no contexto de ensino e aprendizagem de línguas (O’DOWD, 2013). O presente estudo buscou compreender como a co-construção da interculturalidade ocorreu em um contexto de telecolaboração específico - o teletandem (TELLES; VASSALLO, 2006; TELLES, 2015a, 2015b). Para as análises, foram incluídos dados de uma sessão de teletandem, de uma sessão de mediação, de um relato de experiência e de uma entrevista. Dentro de uma perspectiva ecológica (VAN LIER, 2004; KRAMSCH; STEFFENSEN, 2008), os resultados mostraram que a co-construção da interculturalidade foi um processo, ou seja, ela ocorreu ao

\footnotetext{
${ }^{1}$ This article is from my Ph.D. dissertation (SCHAEFER, 2019), which was written under the supervision of professor Dr. Gloria Gil.
} 
longo do tempo e a partir de diferentes instâncias. Em outras palavras, instâncias posteriores à sessão de teletandem, por exemplo, sessão de mediação e relato de experiência, foram essenciais para a referida co-construção.

PALAVRAS-CHAVE: interculturalidade; teletandem; telecolaboração; intercâmbio intercultural online; ensino e aprendizagem de línguas estrangeiras online.

\section{Introduction}

Telecollaborative exchanges, made possible by the use of digital technologies, foster the contact between members of different cultures. For O'Dowd (2013, p. 123), telecollaboration is related to "the application of online communication tools to bring together classes of language learners in geographically distant locations to develop their foreign language skills and intercultural competence through collaborative tasks and project work."

One of the modes of telecollaboration is teletandem (TELLES; VASSALLO, 2006; VASSALLO; TELLES, 2006; VASSALLO, 2009; TELLES, 2011, TELLES, 2015a, 2015b), which is also the specific context of this study. It can be characterized as videoconferencing between two interactants ${ }^{2}$ who are learning each other's language (VASSALLO, 2009), in which they swap their roles: at times as learners of a foreign language and at other times as tutors of their mother tongue or other languages.

Teletandem, which includes resources such as voice, image and writing, has three guiding principles: reciprocity, autonomy and the use of separate languages (VASSALLO; TELLES, 2006; TELLES, 2015b). Reciprocity, according to Brammerts (1996), refers to a mutual support and interdependence between the two language learners, whereas autonomy is related to the commitment of both interactants regarding their own learning process. The use of separate languages, in turn, means that the two languages cannot be mixed (VASSALLO; TELLES, 2006; TELLES, 2015b).

Bearing in mind that, as was explained earlier, telecollaboration provides the contact among people from different cultures, this study sought to understand the way in which the co-construction of interculturality took place in the investigated teletandem activities. To achieve this objective, I

\footnotetext{
2 "Interactants" is the name given to the two partners who are learning each other's language in teletandem sessions. Sometimes I will make use of "interactant(s)" instead of "participants", even though most of times I use the latter.
} 
outlined the following research question: how did the co-construction of interculturality take place in the investigated teletandem activities?

The way in which this study can contribute to the teletandem context can be explained by two main reasons. About the first, the need to look at cultural aspects in the thematic project Teletandem Brasil: foreign languages for all (henceforward TTB) ${ }^{3}$ was pointed out by Telles (2011). Similarly, Telles (2015b) highlights that "the intercultural dimension of teletandem interactions has not been sufficiently explored" (p. 4). Concerning the second reason, I adopted an ecological perspective (henceforward EcP) ${ }^{4}$ (HAUGEN, 2001; VAN LIER, 2004; KRAMSCH; STEFFENSEN, 2008), which, in a more holistic view (KRAMSCH; STEFFENSEN, 2008), can help to draw attention to different instances beyond the teletandem sessions. In this way, this study seeks to bridge a gap by focusing on interculturality through an ecological view.

This text is divided into five sections. The first focused on the purpose of this investigation and, in addition, presented a brief contextualization of the object of study. In the second section, I deal with the relevant literature to ground this study, while in the third I address the method used. Then, in the fourth section, I present the data analysis. Moreover, on the basis on the data analysis, I show the way in which the co-construction of interculturality took place. Lastly, in the fifth section I make final considerations and, besides that, I offer some suggestions for further research.

\section{Review of the Literature}

\subsection{Sociocultural Theory}

Knowledge is considered to be socially co-constructed in teletandem, the specific "mode of telecollaboration" (TELLES, 2015a, p. 604) in my study. Actually, according to Telles (2015a), teletandem was conceived and developed on the basis of Sociocultural Theory (henceforward SCT).

In line with Vygotsky $(1978,1986)$, knowledge and meanings are socially co-constructed through language. Vygotsky (1978) argues that learning happens first socially and, subsequently, higher mental functions

\footnotetext{
${ }^{3}$ The TTB project will be explained further below.

${ }^{4}$ The EcP will be presented further on.
} 
are developed. Furthermore, the author explains that historical and cultural features contribute to this development. From this perspective, individuals are part of a particular cultural context through which they learn by coconstructing and negotiating social meanings.

One of the central aspects of SCT is mediation, also called "symbolic mediation". For Vygotsky $(1978,1986)$, the relation of the human being with the world is not direct, but mediated through the following elements: 1) instrument and 2) sign. The first mediating element, the instrument, increases the possibilities of the transformation of nature and regulates the actions on the objects when human beings interact with the world around them. For example, the use of the computer (instrument) in teletandem allows for the contact between two people who seek to learn each other's language. The second mediating element, the sign, has the capacity to bring about internal changes, since it regulates actions on people's psyche. The author explains that language is a central psychological instrument, because through it human beings can develop higher mental functions.

Another central construct in SCT is The Zone of Proximal Development (henceforward ZPD). Vygotsky (1978, p. 86) defines this concept as "the distance between the actual developmental level as determined by independent problem solving and the level of potential development as determined through problem-solving under adult guidance, or in collaboration with more capable peers" (1978). In this "zone", therefore, people who are more experienced help others, who are less experienced, to learn and become more autonomous within their potential. For instance, in teletandem sessions, through collaborative learning, one participant helps the other to learn a language. Closely related to ZPD, the concept of scaffolding, introduced by Wood, Bruner and Ross (1976), refers to the support mechanism that helps the less experienced to learn in their ZPD where necessary. For the authors (p. 90), such a support "enables a child or novice to solve a task or achieve a goal that would be beyond his unassisted efforts."

For Vygotsky (1981), the development and transformations of individuals occurs on the basis of four genetic domains: phylogenetic, ${ }^{5}$

\footnotetext{
5 "Phylogenetic" refers to the evolution of living organisms by means of their gradual adaptation to the environment. This evolution occurs through a slow process of transformation over long periods of time.
} 
sociocultural, ${ }^{6}$ microgenetic and ontogenetic. Two of these genetic domains, which are fundamental in this work, are the "microgenetic" and the "ontogenetic". Microgenetic concerns specific situations that are experienced by individuals which can modify their higher mental functions. Ontogenetic, on the other hand, involves the entire history of each individual, and the different transformations that, through dialectical interactions, occur throughout her/his life, from birth to adulthood. From an EcP, Van Lier (2004, p. 12) claims that the ontogenetic realm "includes the interactional processes in which social meanings become internalized, and the use of language and signs, linked with the development of higher mental functions."

\subsection{Ecological Perspective}

Van Lier (2004) makes clear that SCT is consistent with an EcP, as it can help to provide a situated and contextualized outlook on meaning negotiation, which is socially co-constructed.

Van Lier (2004) asserts that an EcP concentrates on the relationships that language learners establish with the environment, as the latter has symbolic, physical and social characteristics that can exert influence on their interaction. In a similar fashion, this perspective, according to Haugen (2001, p. 57), focuses on the "study of interactions between any given language and its environment."

Kramsch and Steffensen (2008, p. 18) state that one of the central features of the EcP is holism, which presupposes that "everything is part of an undividable whole" and that language cannot be viewed as a mere system of rules, closed, abstract, finished and dissociated from the interference of the social. For the authors, a holistic view has three characteristics. The first is interaction, which refers to the idea that there is not a monodirection relationship amongst individuals, but rather mutuality, meaning that all parties are affected in a variety of ways. Interconnectedness, the second characteristic, stands for the connection between each part of the whole with any other parts and the whole. Finally, the third characteristic, interdependence, "implies that a linguistic phenomenon's mode of existence changes if other phenomena change or cease to exist" (KRAMSCH; STEFFENSEN, 2008, p. 18).

6 "Sociocultural" since social interactions are the basis of higher cognitive processes. 


\subsection{Telecollaboration, Teletandem and Interculturality}

O'Dowd (2013) makes it clear that telecollaboration ${ }^{7}$ has had extensive presence in research and activities in the area of foreign language teaching and learning for more than three decades. The author adds that, from the mid-1990s, an increased attention to social and intercultural aspects "led to the emergence of more complex forms of exchange" (p. 128) in telecollaboration, when compared to years prior to the aforementioned period.

Three examples of telecollaborative projects are (1) The Cultnet Intercultural Citizenship, which aims at including citizenship education in the teaching and learning of languages through subprojects (BYRAM, 2016); (2) The Cultura Exchange Programme, whose objective is to enable the intercultural contact between students from different countries (FURSTENBERG, 2016); and (3) Teletandem Brasil: foreign languages for all (henceforward TTB) ${ }^{8}$ (TELLES; VASSALLO, 2006; VASSALLO; TELLES, 2006; TELLES, 2011, 2015a, 2015b), created in 2006 and developed by a state university in São Paulo's countryside, which enables college students from Brazil to interact with college students from other countries. In TTB, the specific telecollaborative project analyzed in the present study, the online sessions can take place through tools such as Skype or Zoom. ${ }^{10}$

Dialogue, which, according to Kramsch and Steffensen (2008), is at the heart of an EcP, can be fostered between language learners from different cultures in teletandem and other telecollaborative projects. Indeed, telecollaboration is regarded by different researchers as an opportunity for the intercultural dialogue. For instance, Helm (2016) underscores that dialogue "entails critical thinking and aims to reveal assumptions and biases, so they can be re-evaluated" (p. 153). It is through dialogue, therefore, and by working collaboratively, that "participants explore identities and difference, personal experience and emotions, which contribute to

\footnotetext{
${ }^{7}$ Most recently, the term Online Intercultural Exchange (OIE) has also been used to refer to "telecollaboration".

${ }^{8}$ See http://www.teletandembrasil.org/ for further information on TTB.

${ }^{9}$ Skype is a software that provides voice and video communications via the Internet.

${ }^{10}$ Zoom combines online meeting, video conferencing and mobile collaboration. It also provides cloud-based video communication.
} 
awareness of self and others" (p. 153). O'Dowd (2003, p. 133), in turn, asserts that the intercultural dialogues "allow learners to express their ideas and then to clarify and redefine them through feedback and through the other perspectives to which they are exposed." Finally, Veloso and Almeida (2009) argue that dialogue in teletandem enables interactants to take a major control over the learning process and prevents them from being consumers of teaching syllabi.

Cultural differences, according to Kern (2014), Helm (2016), and O'Dowd (2016), are not often discussed in more depth in telecollaborative exchanges, and the discussion about such cultural differences is frequently averted. For Helm (2016, p. 151), this happens because language learners' focus "is on phatic exchanges between learners and [there is] a concern to avoid tensions and misunderstandings." As stated by O’Dowd (2016), learners do not go deeper in cultural differences because they tend to pay more attention to "what cultures may have in common at a superficial level" (p. 277), which can "have little effect on students' understanding of the partner culture or to lead to a critical reflection on students' own culture" (p. 277). In addition, avoiding deeper discussion "can lead to 'missed' communication, or missed opportunities for approximating the kind of rich, meaningful intercultural learning that instructors often intend with telecollaborative projects" (WARE, 2005, p. 66).

In most telecollaborative projects reported in research "teachers organize the communication and tasks, motivate students, monitor activities and provide feedback and support for learners, but the communication between learners is not usually moderated" (HELM, 2016, p. 151). Specifically concerning the context of teletandem, the online sessions themselves are not moderated by a teacher-mediator either. Mediation sessions (TELLES, 2015b, LEONE; TELLES, 2016; LOPES; FRESCHI, 2016) are nevertheless an essential way of facilitating, according to Lopes and Freschi (2016), moments of further reflection and the questioning of essentialist views. Leone and Telles (2016, p. 244) define mediation session as follows:

Moments that follow interactions in teletandem. During these sessions, students have the opportunity to dialogue and exchange experiences with a mediator - a teacher of foreign languages. These discussions focus on (a) aspects of language, (b) culture and (c) partners' relationship. The 
mediation activity aims at giving students a teacher supported context (scaffolding) to reflect on the teaching and the learning experiences during the teletandem session.

Regarding telecollaborative contexts in general, it could be said that gaining knowledge of other people's values and behaviors, respect for other cultures, adaptation to different contexts, openness to other viewpoints and personal desire to know other cultures are relevant aspects when it comes to the construction of interculturality, which Byram (1997) actually names intercultural communicative competence. For him, this term is related to the ability to use language in interactions with people from other cultures. He adds that, for the development of such a competence, it is paramount that language learners "elicit from an interlocutor the concepts and values of documents and events" (p. 53).

Byram (1997) proposes five components (or what he names savoirs) for the development of intercultural communicative competence, namely: (1) attitudes (or savoir être), which are related to a "willingness to suspend belief in one's own meanings and behaviors, and to analyze them from the view point of the others with whom one is engaging" (p. 34); (2) knowledge (or savoirs), referring to knowledge of other cultures and the self in social interactions; (3) skills of interpreting and relating (or savoir comprendre), that is, "the ability to acquire new knowledge of a culture and cultural practices and the ability to operate knowledge, attitudes and skills under the constraints of real-time communication and interaction" (p. 61); (4) skills of discovering and interacting (or savoir apprendre/faire), meaning that it is necessary to have the ability to interpret documents or events of other cultures and relate them to their own cultural horizons; and (5) critical cultural awareness (or savoir s'engager), which stands for the examination and interpretation of cultural differences.

Kramsch (1993) explains that meaning-makings are an interpersonal process, since they emerge through interaction with "the other". This way, the reflection between "the self" and "the other" in intercultural interaction presupposes the deconstruction of fixed cultural representations as well as of the world itself. Kramsch (2005, p. 553) adds that such a reflection can lead to interculturality, which is related to "an awareness and a respect of [sic] difference, as well as the socio-affective capacity to see oneself through the eyes of others." In the same vein, Bredella (2002, p. 39) states that 
interculturality is the ability to "reconstruct the context of the foreign, take the others' perspective and see things through their eyes. This implies that we are able to distance ourselves from our own categories, values and interests." In this respect, Byram, Gribkova and Starkey (2002, p. 29) emphasize that a decentering process can help language learners "to step outside their taken for granted perspectives", while Liddicoat and Scarino (2013) assert that it makes it possible "to see the unfamiliarity of the cultural representations" (p. 116), as well as the "transformational engagement of the learner" (p. 42).

In 1993, Kramsch coined the term the third place, which stands for a hybrid space where a constant mediation between different cultures occurs. At the third place, such a mediation can help language learners to decenter themselves from cultural representations. More recently, Kramsch (2011, p. 354-355) defined the third place as "a sphere of interculturality that enables language students to take an insider's view as well as an outsider's view" regarding cultural representations.

The third place can be associated with two metaphors: discursive faultines (KRAMSCH, 1993; MENARD-WARWICK, 2009) and transgredience (KRAMSCH, 2013). For Kramsch (1993), discursive faultlines concern the moments in which cultural representations are contested at the third place. As explained by Menard-Warwick (2009, p. 30), these discursive faultlines, that is, "areas of cultural difference", are "pedagogically valuable because they index the cultural areas that need to be explored in order to work toward interculturality." The second metaphor, transgredience (KRAMSCH, 2013, p. 62), is related to the idea that language learners, through a critical eye, can "occupy a position where they see themselves both from the inside and from the outside" as well as "reflect on their experience." According to Byram, Gribkova and Starkey (2002, p. 29), such a critical stance can help language learners "to act on a [sic] the basis of new perspectives."

Telles's (2015b) study, which focused on interculturality in the teletandem context, had two objectives: 1) to show how Performative Theory ${ }^{11}$ can help to understand how the constitution of national identities occurs and 2) to reflect on pedagogical implications upon foreign language pedagogy. The author argues that "teletandem discourse is basically characterized by performances of differences" (p. 5), and adds that learners'

\footnotetext{
${ }^{11}$ For Kulick (2003 as cited in TELLES, 2015b, p. 6), "performativity is the process through which the subject emerges" (p. 140).
} 
stable and essentialized conceptions of the world "are performatively produced and not merely represented in their (intercultural) discursive practices" (p. 7). Hence, as meaning is performatively produced, Telles (2015b) alerts that teletandem sessions "may fall into shallow performances of sedimented and pre-given representations of self and other" (p. 1), meaning that the discussions in teletandem "involve common sense, and are essentialist in nature" (p. 4). Excerpts from three teletandem sessions of a partnership between a learner of Portuguese and a learner of English were analyzed. The analysis showed that teletandem is a context where participants can express ideologies and their subjectivities. Although the author did not analyze data from mediation sessions, Telles points out that these moments can promote critical thinking as well as "critical appreciation of identity and difference" (p. 25) if appropriately and critically explored by teacher-mediators.

Lopes and Freschi (2016) also concentrated on interculturality in teletandem. Their study aimed at discussing the relevance of the identification of potential sequences for intercultural learning (BORGHET'TI; BEAVEN; PUGLIESE, 2015) ${ }^{12}$ as opportunities for the development of intercultural competence $^{13}$ in mediation sessions. To achieve this goal, excerpts from four teletandem sessions of different partnerships were analyzed. Through the analysis, the authors identified potential sequences for intercultural learning, e.g. prejudice and essentialized worldviews. They argue that "what an interactant says about himself/ herself, about his/her culture and his/her people is not usually questioned by his/her partner" (p. 55, own translation). ${ }^{14}$ The authors did not include data from mediation sessions in their corpus, but they indicated the relevance of addressing in these sessions topics that were previously identified in teletandem sessions as potential sequences for intercultural learning.

${ }^{12}$ For Borghetti et al. (2015), such potential sequences involve the following: (1) exemplifications and equivalences between phenomena, (2) communicating understandings to others and (3) adapting to others' contributions.

${ }^{13}$ Drawing on Belz (2003), Lopes and Freschi (2016) define intercultural competence as "the awareness and/or understanding of foreign attitudes, their beliefs, as well as their linguistic practices" (p. 50, own translation).

${ }^{14}$ Original quote: "aquilo que um interagente diz de si mesmo, de sua cultura e de seu povo não costuma ser questionado pelo parceiro". 
As can be seen, both Telles's (2015b) study and Lopes and Freschi's (2016) study pointed out that research dealing with fixed cultural representations in mediation sessions in the teletandem context is necessary. This is because teletandem sessions can be a site for the construction of essentialized views with regard to people, countries, cultural references, and so forth.

In short, given that telecollaborative spaces facilitate the dialogue between people from different cultures, they can open pathways for the reflection between "the self" and "the other", which, as a result, may help in the process of the co-construction of interculturality. Furthermore, especially under the guidance of a teacher-mediator in the context of telecollaboration, as was explained previously, dialogue can help language learners to distance themselves from "their preexisting assumptions and practices” (LIDDICOAT; SCARINO, 2013, p. 26).

\section{Method}

The data used in this study ${ }^{15}$ were collected in a specific telecollaborative project, TTB, referred to in section 2, between September and December 2016. During that period, the author was a teacher-mediator at TTB and collected data for his doctoral research. ${ }^{16}$

As will be explained below, this qualitative research ${ }^{17}$ can be deemed as a case study (DUFF, 2014) since it looked at a contemporary phenomenon in its real context. For Duff (2014, p. 233), case studies "are normally studied in depth in order to provide an understanding of individuals' experiences, issues, insights, developmental pathways, or performance within a particular linguistic, social, or educational context."

\footnotetext{
${ }^{15}$ The data are from a research project duly approved by Research Ethics Committee of Universidade Federal de Santa Catarina (Comitê de Ética em Pesquisa com Seres Humanos CEPSH-UFSC), logged under Approval Number 1.762.956. CAAE: 56955216.8.0000.0121.

${ }^{16}$ The data used in this study are therefore from my investigation (SCHAEFER, 2019), which focused on interculturality in teletandem. The research results revealed aspects that hindered and others that favored the co-construction of interculturality, e.g. "stereotyped views" and "the emergence of rich points".

${ }^{17}$ For Patton (1985, p. 1), a qualitative research presupposes "an effort to understand situations in their uniqueness as part of a particular context and the interactions there."
} 
Therefore, precisely because it is a case study, this piece of research included two participants in particular regarding the teletandem sessions: Carine and Victoria. ${ }^{1819}$ They were part of a teletandem partnership between a state university in Brazil, where TTB is developed, and a university in the United States. Carine, a Brazilian citizen, was 27 years old at the time of the data collection and was a learner of English. Victoria, a U.S. citizen, was also 27 years old and was a learner of Portuguese.

The excerpts analyzed below were taken from (a) 1 out of 10 teletandem sessions; (b) 1 out of 8 mediation sessions; (c) 1 out of 10 experience reports and; (d) 1 out of 13 interviews. The teletandem session between Carine and Victoria was video-recorded through the application Zoom. In the mediation sessions, which occurred soon after the teletandem sessions, Carine, other participants of the Brazilian university and the teacher-mediator were able to discuss different aspects related to the online sessions. Through experience reports via Google Forms, ${ }^{20}$ Carine had the opportunity to collect her thoughts and submit personal impressions regarding her weekly partnership with Victoria. Carine also participated in interviews, through which I could better understand what she had addressed in her experience reports. The interview and the mediation session were audio-recorded.

For Dörnyei (2007, p. 38), in qualitative research the findings are "ultimately the product of the researcher's subjective interpretation of the data". In fact, the data collected underwent a long process of interpretation and reflection. Therefore, to understand the way in which the co-construction of interculturality took place, I triangulated my interpretations regarding the data from the teletandem session with the data from the mediation session, as well as with Carine's experience report and the interview. As stated by Maxwell (1996), triangulation decreases the risk that the outcomes of a study reproduce biases or limitations of a single procedure. Hence, in line with the EcP (HAUGEN, 2001; VAN LIER, 2004; KRAMSCH; STEFFENSEN, 2008), which actually provided the theoretical

\footnotetext{
${ }^{18}$ Fictitious names in order to safeguard the participants' identity.

${ }^{19}$ For ethical issues, a consent form (Free and Informed Consent Term) was signed by all the participants in this study.

${ }^{20} \mathrm{On}$ Google Forms, it is possible to create virtual forms, e.g. open-ended, multiple choice and evaluation questions.
} 
backdrop for this study, I was able to look beyond teletandem sessions, that is to say, I could have a more holistic look as concerns this study's data.

The six excerpts analyzed in this study refer to "culture-related sets of episodes" (TELLES; ZAKIR; FUNO, 2015), ${ }^{21}$ that is, sets of several interactive episodes where the following cultural topic was discussed: "cultural differences between the State of São Paulo and the Northeast of Brazil". I outlined the following criteria to choose the cultural topic in question: 1) it was discussed more or less deeply along the teletandem session, since many times interactants began to address a topic but shortly after changed it completely; 2 ) it portrayed cultural representations (cultural values and peoples' behaviors); and 3) it was approached again in instances subsequent to the teletandem session.

To facilitate and optimize the transcription process, I used Transana. ${ }^{22}$ The data from the videos and audios were not fully transcribed, only the parts deemed to be relevant for analysis (ERICKSON; SHULTZ, 1981). I translated the excerpts from Portuguese to English, of which I take full responsibility.

Regarding the excerpts, I used "C" referring to Carine, "V" to Victoria, "T" to Tiago, "E" to Eloá and "R" to the researcher. Tiago and Eloá, Brazilian citizens and learners of English, participated in the mediation session.

The information between two parentheses, that is, $(())$, as transcription conventions ${ }^{23}$ are related to the researcher's comments.

\footnotetext{
${ }^{21}$ For Telles, Zakir and Funo (2015, p. 374), episódios relacionados à cultura (culture-related episodes) refer to "any part of a dialogue in which the focus is on some explanation, questioning or curiosity about aspects of one's own culture or the partner's culture" (own translation). In my study, I borrowed from the authors the concept "culture-related episodes" but, due to specificities of my investigation, I adapted it to "culture-related sets of episodes".

${ }^{22}$ See http://www.transana.org/ for further information on transana program.

${ }^{23}$ I used the transcription criteria proposed by Marcuschi (1997). Researchers in teletandem, such as Zakir (2015) and Souza (2016), transcribed their research data based on Marcuschi's (1997) transcription proposal, with adaptations. Due to specificities of my data, I decided, on the basis of the criteria proposed by the author, to create my own transcription criteria.
} 


\section{Data Analysis}

Whereas it is quite common that, in order to get to know each other, participants introduce themselves in the first teletandem session, Carine, the participant of the Brazilian University, and Victoria, the participant of the American University, provided information on their age, what they were studying, their personal preferences, and so forth. In response to a question from her partner, Carine explained that she was born in a city of the State of São Paulo, and that she was currently living in this same state but in another city. She also noted that she had already lived in two states in the Northeast of Brazil. The coming excerpt depicts the impressions that Carine had of having lived in these places:

1. C: But it's ((the Northeast)) COMPLETELY completely different from here.

2. V: Yeah.

3. C: I I maybe I... when I lived there I thought ah... they are... ah... here and there are different countries... ah... for me it's similar like that because ah...

4. V: Yeah.

5. C: The weather is very different the food is different the behavior of the people is different... ah... the the... way to... the way to... ((facial expression indicating that she did not know how to say in English)) ah...

6. V: Say that in Portuguese... ((laughing)) ((they both laughed)) I need to practice.

((in turns (7) and (9), Carine alternated her speech between Portuguese and English))

7. C: O... o... obrigada o jeito das pessoas se vestirem é muito diferente ${ }^{24}$ it's very different.

8. V: Uh-huh. ${ }^{25}$

\footnotetext{
${ }^{24}$ Own translation: "the way how people dress is very different".

${ }^{25}$ The interjection "uh-huh", in English, is used, according to Cambridge Dictionary (see https://dictionary.cambridge.org/dictionary/english/uh-huh), "to agree with or show understanding of something that has just been said", as well as "to express agreement to what has just been said, or to mean yes".
} 
9. C: The clothes are different $a h . . e e u^{26}$ yes ((giving a shy laugh)) it's very different... maybe because there it's ah very hot and here is colder and the people ah... ((facial expression indicating that she did not know how to say in English)) esqueci de falar (incompreensible) mas as pessoas se vestem de uma forma diferente... eu acho que aqui no Estado de São Paulo... nós somos um pouco mais conservadores... ${ }^{27}$

10. E: Huh. ${ }^{28}$ (Excerpt 1 / teletandem session / original in English / Carine and Victoria / 28-09-2016).

As is evident from this excerpt, Carine created representations of two cultural entities: the two states of the Northeast, where she had lived, and the State of São Paulo, where she was born and was currently residing. Some binary oppositions pertaining to these two larger entities evoked by Carine are "here is colder vs there is hotter", "the food from here vs the food from there" and "here people are more reserved vs there people are less reserved". This "marking of difference" meets Telles (2015b, p. 5), for whom "teletandem discourse is basically characterized by performances of differences." In effect, Carine constructed these identities on the basis of the comparison between the cultural groups in question, and, through these markings of difference, she put forward particular characteristics which help to indicate her connection with both the State of São Paulo and the two states of the Northeast.

In turn (9), Carine displayed an essentialized view concerning people of the State of São Paulo when she claimed that "we are a little more conservative". Hence, in her discourse it is implied that she is among the people in this larger entity (the State of São Paulo) who are "a little more conservative", as opposed to the people of the other larger entity (the two Northeastern states), who are "less conservative". As stated by Telles (2015b), essentialized cultural representations, such as the ones verbalized by Carine, are characteristic in teletandem sessions.

\footnotetext{
${ }^{26}$ Own translation: "I".

${ }^{27}$ Own translation: "I forgot to say (incomprehensible) but people dress in a different way... I think that here in the State of São Paulo... we are a little more conservative...". ${ }^{28}$ In English, the interjection "huh" ("hum" in Portuguese), can indicate, according to Written Sound (see http://www.writtensound.com/index.php?term=huh), affirmation, surprise, disbelief, agreement, among other possibilities.
} 
Echoing Kern (2014), Helm (2016) and O’Dowd (2016), it can be argued that the meaning negotiation in this dialogue achieved a superficial level. Firstly, the cultural differences voiced by Carine were not discussed in more detail, and she actually smoothed over them. In line with Ware (2005, p. 66), an opportunity to go deeper into the cultural topic in question was missed, which the author calls "'missed' communication". Secondly, Victoria did not contest Carine's generalizing subject positions in the discursive faultlines (KRAMSCH, 1993; MENARD-WARWICK, 2009), nor did she put forward her points of views in reaction to the cultural aspects pointed out by Carine, especially when the latter claimed that people from the State of São Paulo are a little more conservative. As Lopes and Freschi (2016) reminded us, in teletandem sessions, the two partners do not generally question each other's comments. In addition, Helm (2016) remarks that in telecollaboration there seems to be a tendency to avoid issues that require further investigation or that are of a more complex nature.

Shortly after in that teletandem session, Carine said the following: "it's very interesting... ah... having lived there ((in the two states of Northeast)) and to be able to compare... to have these two visions" (own translation from Portuguese). However, although it is necessary to open up to the "other" in intercultural interactions and compare different cultures (BYRAM, 1997), as Carine did in this excerpt, her comparisons remained restricted to a personal level and her cultural representations were not problematized.

Despite the fact that in teletandem sessions there is always the presence of the other, Carine and Victoria's online interaction in Excerpt 1 seems to have taken more the form of a monologue than a dialogue itself, which appears to be linked to the superficial level of meaning negotiation. According to Helm (2016, p. 153), through dialogue "participants explore identities and difference, personal experience and emotions." It was nonetheless Carine who made comments most of the time in this excerpt, while Victoria did not present her vision or raise questions. The latter only answered with "uh-huh", "yeah", or "huh", most likely to indicate that she was hearing Carine or agreeing with her. This is perhaps one of the reasons why the meaning negotiation remained superficial and possibly why Carine did not have the chance to redefine some of her points of view.

In the mediation session a month and a half later, where Tiago and Eloá were also present, the topic about cultural differences between the 
two Northeastern states vs. the State of São Paulo was again referred to by Carine. The following excerpt, taken from the sixth mediation session, illustrates how Carine addressed this topic after Tiago expressed outrage over the fact that his online partner Johnny, a U.S. citizen, had asked him if he was keeping an affective relationship with someone:

1. T: I feel a bit... ashamed (incomprehensible) already wants to know about my life...

2. E: It's more like the opposite right? like Brazilians want to know more intimate things and then Americans think "huh... this guy?"

3. T: ((he laughed)) YEAH!

4. C: But today I discussed something with Victoria I found it very... as you were saying... like... I think that Paulista in general... I was talking to her... there are some cultural differences like... and Paulista we ARE a little more conservative like we are we are colder... when compared to Northeast for example... then she said like ah she found it interesting this... this difference... because people have an idea that Brazilians are very open IT'S NOT LIKE THIS.

5. E: I think that in Rio Grande do Sul like the South even MORE reserved. (Excerpt 2 / mediation session / own translation from Portuguese / 16-11-2016).

Both Eloá in turn (2) and Carine in turn (4) attributed characteristics to people in terms of larger and fixed entities, and generalizations of this nature also occurred on the part of Eloá in turn (5). Carine used "in general" in turn (4) probably with the intention of making it clear that her comment did not regard all the people from these regions, even though a predominant homogeneous tone is echoed. The next excerpt shows how I positioned myself in reaction to the participants' comments in that mediation session:

1. R: I see that differences are much more individual than necessarily whether I am Brazilian or whether I am from the region X and so on... $[\ldots]$ then I also think that it's a matter of the... of the... individual.

2. C: Yes.

3. R: That is, each person receives according to her/his history... according to what she/he thinks... to her/his convictions... isn't it? of course... there can be also influence of where the person is... of where she/he lives in of where she/he comes from... everything... right?

((Tiago went back to talking about the topic that had triggered this discussion)) 
4. R: And what do you think of this of what I explained do you agree with or not?

5. C: I agree.

6. ((other participants said "yes"))

7. R: Really?

8. C: Not necessarily the region but the person.

9. E: Point of view.

10. C: Yes point of view stereotypes. (Excerpt 3 / mediation session / own translation from Portuguese / 16-11-2016).

In turns (1) and (3), I attempted to make my participants aware that perspectives and behaviors also vary from person to person and that these cultural differences are not solely related to the fact that people pertain to a specific social group. Carine in turns (5), (8) and (10), other participants in turn (6) and Eloá in turn (9) agreed with me, and in turn (8), Carine proved to be able to capture the essence of my positioning when she said "not necessarily the region but the person". Taking into account that it is necessary to challenge stereotyped representations (TELLES, 2015b; LOPES; FRESCHI, 2016) and suggest other viewpoints (BYRAM; GRIBKOVA; STARKEY, 2002), this excerpt illustrates how I provided the participants with a different perspective as regards the topic under discussion.

It can be claimed that the co-construction of interculturality was taking place in Excerpt 3. As Kramsch (2011, p. 364) puts it, to open pathways for the deconstruction of fixed representations, teachers should "bring up every opportunity to show complexity and ambiguity". In this way, I suggested and brought forward other viewpoints (BYRAM; GRIBKOVA; STARKEY, 2002) in turns (1) and (3), since I was interested in having my participants interpret the cultural topic in question from a different angle. This seems to have given vent, in turns (8) and (10), to an initial process of Carine's displacement from her cultural generalizations. Byram (1997) names such a process savoir être, while Kramsch (2013) calls it "transgredience" (p. 62).

Later, in her third-to-last experience report, Carine returned to the issue of the two states of the Northeast where she had already lived vs. the State of São Paulo: 
I said that, in general, people born in the North or Northeast of the country tend to be much warmer than those born in the Southeast region [...] maybe I am more "Paulista" than I would like to be and perhaps this fact gives me unwillingly some more or less common marks, although there are always exceptions. (Excerpt4 / Carine's experience report / own translation from Portuguese / 30-11-2016).

As was the case in Excerpt 3, it can be said that the co-construction of interculturality was in progress in Excerpt 4 when compared to Carine's prevailing homogenous tone in Excerpts 1 and 2. It is remarkable how this participant, in this experience report, drew upon modalizations such as "in general", "tend to be", "more or less common" and "there are always exceptions". For Belz (2007, p. 156), one of the markers of the construction of interculturality "might be a gradual softening of the way in which one positions herself with respect to the 'absolute' truth of utterances" as well as the "decrease in the use of negative judgment over the course of a partnership" (p. 156). To put it another way, while in Excerpts 1 and 2 Carine had demonstrated a tendency to place people's characteristics of the two larger entities in question "in the same box", she probably used, in Excerpt 4 , modalizers to sidestep fixed cultural generalizations.

\subsection{How did the co-construction of interculturality take place in the investigated teletandem activities?}

As has already been said, the following research question was outlined in this study: how did the co-construction of interculturality take place in the investigated teletandem activities? It was explained in the section Review of Literature that two of the four genetic domains for the study of higher mental functions are microgenetic and ontogenetic (VYGOTSKY, 1981). As regards the former, the analysis itself of each of the four excerpts presented previously can be defined as microgenetic, since my outlook was focused on the different "microevents" where meaning negotiation was taking place. Regarding the other domain, ontogenetic, there were other instances directly linked to these "microgenetic situations", which were interactively involved in the process of the co-construction of interculturality. Having said that, drawing on the data analysis presented previously and in response to the research question stated above, I will explain further along how the co- 
construction of interculturality was a process (ontogenetic), as it occurred over time and through different instances.

I should likewise clarify that I will continue to use an EcP (HAUGEN, 2001; VAN LIER, 2004; KRAMSCH; STEFFENSEN, 2008) to support my arguments in this discussion. As already explained, holism is one of the central features of the EcP (KRAMSCH; STEFFENSEN, 2008), in the sense that it addresses particular aspects of interactions. Therefore, this perspective provided a rather organic vision to help me develop this discussion.

As was seen in Excerpt (1), Carine's generalizations about the topic's cultural differences between the State of São Paulo and the Northeast of Brazil remained unchallenged in the teletandem session. Furthermore, meaning negotiation in this online session was superficial (TELLES, 2015b; HELM, 2016; LOPES; FRESCHI, 2016; O'DOWD, 2016). Later, she would come back to the topic about these cultural differences in the mediation session (Excerpt 2).

As has already been seen, one of the characteristics of the collaborative learning, according to Vygotsky (1978), is the role of someone more experienced to find ways to help the less experienced to learn, which he calls ZPD. Specifically in this study, "learning" is linked to the support provided by the teacher-mediator in order to favor the co-construction of interculturality. That is to say, shortly after in the mediation session (Excerpt 3), I offered an "intercultural bridge", or, according to Wood, Bruner and Ross (1976, p. 90), a "scaffolding", to Carine as well as to the other participants, in the sense that I explained to them that perspectives and behaviors also vary from person to person. Furthermore, I highlighted that the cultural differences that were being discussed at that moment were not only associated with the fact that people pertain to a specific social group. Perhaps due to my explanations, at least an initial decentering process (KRAMSCH, 1993, 2005, 2011; BYRAM, 1997; BREDELLA, 2002; BYRAM; GRIBKOVA; STARKEY, 2002; LIDDICOAT; SCARINO, 2013), albeit very timidly, from Carine's cultural representations seemed to be happening when she said "not necessarily the region but the person" and "like points of view stereotypes", which thus indicated that the coconstruction of interculturality was taking place. Further evidence that this co-construction was occurring would emerge later in Carine's experience report (Excerpt 4), since she used modalizers possibly with the intention of 
not generalizing. Indeed, this may have been an outcome of the moment of reflection that had happened in the mediation session (Excerpt 3).

It is important to highlight that even though there were opportunities for the deconstruction of some cultural representation in instances following the teletandem session, it was necessary that Carine initially constructed them in the teletandem session (Excerpt 1) as well as in the mediation session (Excerpt 2). From this perspective, different instances, including the teletandem session, were needed for the co-construction of interculturality.

Telecollaborative exchanges cannot be moderated by a teachermediator (HELM, 2016), as was explained previously. Yet in the case of the mediation session, as a teacher-mediator, I could occupy a position "in-between" my participants, and, at the same time, I acted as the one who fostered moments of in-depth reflection upon cultural representations. Indeed, as already observed, a possible way to promote moments of reflection is through the teacher-mediation's help (TELLES, 2015b, LEONE; TELLES, 2016; LOPES; FRESCHI, 2016). Similarly, Lopes and Freschi (2016) and Telles (2015b) argue that it is necessary to go deeper into cultural essentialisms in the mediation sessions. Thus, to fight against some cultural generalizations, I engaged my participants in dialogue where they had the opportunity not only to talk about different aspects related to their online exchanges, but also to reflect on them. About this, Ware and Kramsch (2005, p. 203) posit that:

As students explore the nature of language and communication across cultures through their technology-mediated interactions, teachers will be pivotal in helping them take [...] an intercultural stance. They can help their students develop a decentered perspective that goes beyond comprehending the surface meaning of words to discovering the logic of their interlocutors' utterances.

Actually, it may be argued that the nature of the discussions in the mediation session converges with the idea that through dialogue, as Helm (2016) reminded us previously, it is possible to unveil cultural assumptions and further discuss them. In this way, the data analysis indicated that through the mediation session (Excerpt 3), Carine had the chance to develop "an intercultural stance", as suggested by the authors' quote above. In other 
terms, through this "intercultural bridge" that I, as a teacher-mediator, had offered, this participant's cultural representations could be contested at the third place (KRAMSCH, 1993, 2011).

Interestingly, in the last interview of the semester, I invited Carine to give her opinion regarding the mediation sessions in general. The following excerpt evinces how she seems to have taken a favorable view about them:

Because there are things I remember that there are things which we talked about in the mediation ((in the mediation session)) and I hadn't thought I said "oh my God it's true!" so... seeing with a different eye opening it right? being able to expand your mind being able to expand your visions I think it's very very relevant very nice. (Excerpt 5 / semi-structured interview / own translation from Portuguese to English / 14-12-2016).

This excerpt shows how Carine acknowledged that through her participation in the mediation session she had come across different perspectives (LIDDICOAT; SCARINO, 2013). This corroborates Lopes and Freschi's (2016) argument, for whom essentialist visions can be submitted to more in-depth discussions in mediation sessions.

In relation to the teletandem activities more broadly speaking, this participant underlined that they provided the following:

A number of things I deemed to be very very valuable right? like... looking with a closer look... as you have much more experience you can... right? you could help us assist us so I think it is very relevant and this made a big difference I think like throughout the process... of the evolution... (Excerpt 6 / semi-structured interview / own translation from Portuguese to English (14-12-2016).

Excerpt 6 clearly demonstrates that Carine had a favorable view about her experience in the teletandem activities. Moreover, her discourse not only in this excerpt, but also in Excerpt 5, may suggest that such an experience helped her to promote a growing awareness of cultural differences, which could be a sign that possible transformations (VYGOTSKY, 1981) or a possible transformational engagement (LIDDICOAT; SCARINO, 2013) of this participant was taking place. 


\section{Final remarks}

As said earlier, as a means of achieving the objective of this study, that is, to understand the way in which the co-construction of interculturality took place in the investigated teletandem activities, I outlined the following research question: how did the co-construction of interculturality take place in the investigated teletandem activities?

To sum up very briefly, and in response to the research question stated above, the results revealed that the co-construction of interculturality was a process, that is, it occurred over time and through different instances. Put differently, instances subsequent to the teletandem sessions, e.g. the mediation session and the experience report, were vital for this coconstruction.

Drawing on the outcomes of this study, it can be argued that interculturality was essentially a decentering attitude, that is, a process of decentering (KRAMSCH, 1993, 2005, 2011; BYRAM, 1997; BREDELLA, 2002; BYRAM; GRIBKOVA; STARKEY, 2002; LIDDICOAT; SCARINO, 2013) from someone's own cultural representations. Linking back to Ware and Kramsch (2005, p. 203), a decentering attitude allows for an "intercultural stance". In fact, such an attitude enabled Carine to look beyond the superficial level of her utterances, and, as was the case in Excerpts 5 and 6 , it appeared that possible transformations (VYGOTSKY, 1981) or a possible transformational engagement (LIDDICOAT; SCARINO, 2013) of this participant was occurring.

The application of different research techniques, mainly the experience reports and the interviews, helped me in understanding more deeply my data, which means that through the use of different methodological resources, I was able to take a more ecological research view, since I could understand more fully my participants, promote deeper reflections and intervene pedagogically whenever needed. Otherwise said, I had the chance to acquire a more holistic view of my data, that is, the interconnection, interaction and interdependence (KRAMSCH; STEFFENSEN, 2008) between my multiple collection instruments. Thus, I suggest that future studies should also include methodological resources, such as the ones I used, but also others where necessary, to better understand the complex process as regards the co-construction of interculturality in the teletandem context. 
In my study, I collected the data over a university semester, making it difficult to determine the extent to which the learning that Carine accomplished was applicable in other situations. For example, it is not possible to know whether this participant indeed continued to address cultural issues "with a different eye", as she explained in the interview (Excerpt 5). What I really want to underline is that longitudinal research in teletandem and other telecollaborative environments could help to understand the process of the co-construction of interculturality over a longer period of time, for instance, two semesters. O'Dowd (2016, p. 284) places emphasis on this need. For the author, studies in telecollaboration "have not attempted to evaluate the impact of virtual contact and exchange on learners over a period any longer than one university semester."

Although this research concentrated on a specific telecollaborative project, TTB, I suggest that opportunities to better understand the process of the co-construction of interculturality are also possible in other projects. Two examples could be The Cultnet Intercultural Citizenship (BYRAM, 2016) and The Cultura Exchange Programme (FURSTENBERG, 2016), described in the introduction, where telecollaborative activities are developed with language learners from different countries and cultures.

The teletandem activities in my study are defined as non-integrated (ARANHA; CAVALARI, 2015; LEONE; TELLES, 2016), which means that they were not bound to classroom contents or to a language syllabus. Bearing in mind that teletandem activities can also be institutionally integrated (ARANHA; CAVALARI, 2015; LEONE; TELLES, 2016), as they "are embedded in regular foreign language lessons" (ARANHA; CAVALARI, 2015, p. 763), future research could focus attention on the process of the co-construction of interculturality in the classroom by having participants reflect upon their online interactions. As O'Dowd (2016, p. 282) puts it, "practically none of the studies used classroom interaction transcripts or field notes to explore how teachers engaged with learners in the analysis of their online interactions."

Finally, drawing upon the results of this study, it can be argued that there is a demonstrable need for the teacher-mediator to be willing to deal with intercultural issues in mediation sessions, in addition to being fully committed to the process of deconstructing some cultural representations. In this respect, Telles (2015b, p. 24) warns that "if the teacher is not critically well informed about such issues, the mediation session may not transcend 
the level of mere reports of experience, in turn perpetuating stereotypes and sedimented conceptions of self and other." With the purpose of facilitating a critical approach regarding the learners' cultural essentialism, teacher-mediators can highlight "complexity and ambiguity" (KRAMSCH, 2011, p. 364) as well as what is underlying the participants' viewpoints, that is, "what remains unsaid" (KRAMSCH, 2011, p. 364). Considering this, teacher-mediators can encourage discussions that go beyond superficial representations.

\section{Acknowledgments}

I am deeply indebted to my supervisor, Dr. Gloria Gil, for having helped me to carry out my Ph.D. research, and to Dr. João Antonio Telles, who kindly opened the doors of the teletandem laboratory for the development of my investigation. I am also particularly grateful to TTB coordinators, teachers and researchers for having spared no efforts to make everything work well during the period of data collection.

\section{References}

ARANHA, S.; CAVALARI, S. M. C. Institutional Integrated Teletandem: What Have We Been Learning about Writing and Peer Feedback? DELTA, São Paulo, v. 31, n. 3, p. 763-780, 2015. DOI: http://dx.doi. org/10.1590/0102-445039175922916369

BELZ, J. A. Linguistic Perspectives on the Development of Intercultural Competence in Telecollaboration. Language Learning \& Technology, Mānoa, Hawai, v. 7, n. 2, p. 68-99, 2003.

BELZ, J. A. The Development of Intercultural Communicative Competence in Telecollaborative Partnerships. In: O'DOWD, R. (ed.). Online Intercultural Exchange: An Introduction for Foreign Language Teachers. Clevedon: Multilingual Matters, 2007. p. 127-166. DOI: https://doi. org/10.21832/9781847690104-009

BORGHETTI, C.; BEAVEN, A.; PUGLIESE, R. Interactions Among Future Study Abroad Students: Exploring Potential Intercultural Learning Sequences. Intercultural Education, [S.l.], v. 26, n. 1, p. 31-48, 2015. DOI: https://doi.org/10.1080/14675986.2015.993515 
BRAMMERTS, H. Tandem Language Learning Via the Internet and the International E-Mail Tandem Network. In: LITTLE, D.; BRAMMERTS, H. (ed.). A Guide to Language Learning in Tandem Via the Internet. Dublin: Centre for Language and Communication Studies, 1996. p. 9-22.

BREDELLA, C. L. For a Flexible Model of Intercultural Understanding. In: ALRED, G.; BYRAM, M.; FLEMING, M. (ed.). Intercultural Experience and Education. Clevedon: Multilingual Matters, 2002. p. 31-49. DOI: https:/ / doi.org/10.21832/9781853596087-006

BYRAM, M. Teaching and Assessing Intercultural Communicative Competence. Clevedon: Multilingual Matters, 1997. 136p.

BYRAM, M. The Cultnet Intercultural Citizenship Project. In: O’DOWD, R; LEWIS, T. (ed.). Online Intercultural Exchange: Policy, Pedagogy, Practice. New York: Outledge, 2016. p. 256-262.

BYRAM, M.; GRIBKOVA, B.; STARKEY, H. Developing the Intercultural Dimension in Language Teaching: A Practical Introduction for Teachers. Strasbourg: Council of Europe. 2002. 41p.

DÖRNYEI, Z. Research Methods in Applied Linguistics. Oxford: Oxford University Press, 2007. 336p.

DUFF, P. Case Study Research on Language Learning and Use. Annual Review of Applied Linguistics, Cambridge, v. 34, p. 233-255, 2014. DOI: https:/ / doi. org/10.1017/S0267190514000051

ERICKSON, F; SHULTZ, J. When is a Context? Some Issues and Methods in the Analysis of Social Competence. In: GREEN, J. L.; WALLAT, C. (ed.). Ethnography and Language in Educational Settings. Norwood: Ablex, 1981. p. 147-160.

FURSTENBERG, G. The CulturaExchange Programme. In: O’DOWD, R.; LEWIS, T. (ed.). Online Intercultural Exchange: Policy, Pedagogy, Practice. New York: Outledge, 2016. p. 248-255.

HAUGEN, E. The Ecology of Language. In: FILL, A.; MÜHLHÄUSLER, P. (ed.). The Ecolinguistics Reader: Language, Ecology and Environment. London: Continuum. 2001. p. 57-66.

HELM, F. Facilitated Dialogue in Online Intercultural Exchange. In: O'DOWD, R; LEWIS, T. (ed.). Online Intercultural Exchange: Policy, Pedagogy, Practice. New York: Outledge, 2016. p. 150-172. 
KERN, R. Technology as Pharmakon: The Promise and Perils of the Internet for Foreign Language Education. The Modern Language Journal, [S.l.], v. 98, n. 1, p. 340-357, 2014. DOI: https://doi.org/10.1111/j.15404781.2014.12065.x

KRAMSCH, C. Context and Culture in Language Teaching. Oxford: Oxford University Press, 1993. 295p.

KRAMSCH, C. Post 9/11: Foreign Languages between Knowledge and Power. Applied Linguistics, [S.l.], v. 26, n. 4, p. 545-567, 2005. DOI: https:/ / doi.org/10.1093/applin/ami026

KRAMSCH, C. The Symbolic Dimensions of the Intercultural. Language Teaching, Cambridge, v. 44, n. 3, p. 354-367, 2011. DOI: https://doi. org/10.1017/S0261444810000431

KRAMSCH, C. Culture in Foreign Language Teaching. Iranian Journal of Language Teaching Research, Urmia, Iran, v. 1, n. 1, p. 57-78, 2013.

KRAMSCH, C.; STEFFENSEN, S. V. Ecological Perspectives on Second Language Acquisition and Socialization. In: DUFF, P. A.; HORNBERGER, N. H. (ed.). Encyclopedia of Language and Education. Dordrecht: Springer Science+Business Media, 2008. p. 17-28.

KULICK, D. No. Language \& Communication, [S.l.], v. 23, n. 2, p. 139-151, 2003. DOI: https://doi.org/10.1016/S0271-5309(02)00043-5

LEONE, P.; TELLES, J. A. The Teletandem Network. In: O'DOWD, R.; LEWIS, T. (ed.). Online Intercultural Exchange: Policy, Pedagogy, Practice. New York: Routledge, 2016. p. 241-247.

LIDDICOAT, A.; SCARINO, A. Intercultural Language Teaching and Learning. Oxford: Wiley-Blackwell. 2013. DOI: https://doi.org/10.1002/ 9781118482070

LOPES, Q. B.; FRESCHI, A. C. Potenciais sequências de aprendizagem intercultural no teletandem: a importância da mediação. Revista do Gel, São Paulo, v. 13, n. 3, p. 49-74, 2016. DOI: https://doi.org/10.21165/gel. v13i3.1470

MAXWELL, J. A. Qualitative Research Design: An Interactive Approach. Thousand Oaks: Sage, 1996. 192p.

MARCUSCHI, L. A. Análise da conversação. São Paulo: Ática, 1997. 94p. 
MENARD-WARWICK, J. Co-constructing Representations of Culture in ESL and EFL Classrooms: Discursive Faultines in Chile and Colombia. The Modern Language Journal, [S.l.], v. 9, n. 1, p. 30-45, 2009. DOI: https://doi. org/10.1111/j.1540-4781.2009.00826.x

O'DOWD, R. Understanding "The other Side": Intercultural Learning in a Spanish-English E-mail Exchange. Language Learning \& Technology, Mānoa, Hawai, v. 7, n. 2, p. 118-144, 2003.

O'DOWD, R. Telecollaboration and CALL. In: THOMAS, M.; REINDERS, H; WARSCHAUER, M. (ed.). Contemporary Computer-assisted Language Learning. London: Bloomsbury Academic, 2013. p. 123-141.

O'DOWD, R. Learning from the Past and Looking to the Future of Online Intercultural Exchange. In: O'DOWD, R; LEWIS, T. (ed.). Online Intercultural Exchange: Policy, Pedagogy, Practice. New York: Outledge, 2016. p. 273-294. DOI: https://doi.org/10.4324/9781315678931

PATTON, M. Q. Quality in Qualitative Research: Methodological Principles and Recent Developments. Chicago: Invited Address to Division Journal of the American Educational Research Association. 1985.

SCHAEFER, R. The Co-Construction of Interculturality in the Project Teletandem Brasil: Foreign Languages for All. 2019. 597f. Dissertation (Ph.D. in English: Linguistic and Literary Studies) - Post-graduate Program in English: Linguistic and Literary Studies, Universidade Federal de Santa Catarina, Florianópolis, 2019.

SOUZA, M. G. Teletandem e mal-entendidos na comunicação intercultural online em lingua estrangeira. 2016. 172f. Tese (Doutorado em Estudos Linguísticos) - Programa de Pós-Graduação em Estudos Linguísticos, Universidade Estadual Paulista, São José do Rio Preto, 2016.

TELLES, J. A. Teletandem: Tranculturalidade nas interações on-line em línguas estrangeiras por webcam. Research Project: Universidade Estadual Paulista, Brazil, 2011. p. 1-24.

TELLES, J. A. Learning Foreign Languages in Teletandem: Resources and Strategies. DELTA, São Paulo, v. 31, n. 3, p. 603-632, 2015a. DOI: https:/ / doi.org/10.1590/0102-4450226475643730772 
TELLES, J. A. Teletandem and Performativity. Revista Brasileira de Linguística Aplicada, Belo Horizonte, v. 15, n. 1, p. 1-30, 2015b. DOI: https://doi. org/10.1590/1984-639820155536

TELLES, J. A.; VASSALLO, M. L. Foreign Language Learning In-tandem: Teletandem as an Alternative Proposal in CALLT. The ESPecialist, São Paulo, v. 27, n. 2, p. 189-212, 2006.

TELLES, J. A.; ZAKIR, M. A.; FUNO, L. B. A. Teletandem e episódios relacionados a cultura. Delta, São Paulo, v. 31, n. 2, p. 359-389, 2015. DOI: https://doi.org/10.1590/0102-445084549183239327

VAN LIER, L. The Ecology and Semiotics of Language Learning: A Sociocultural Perspective. Dordrecht: Kluwer Academic Publishers, 2004. 248 p. DOI: https://doi.org/10.1007/1-4020-7912-5

VASSALLO, M. L. Teletandem ou Tandem Tele-Presencial? In: TELLES, J. A. (org.). Teletandem: Um contexto virtual, autônomo e colaborativo para a aprendizagem de línguas estrangeiras no século XXI. Campinas: Pontes, 2009. p. 185-197.

VASSALLO, M. L; TELLES, J. A. Foreign Language Learning In-tandem: Theoretical Principles and Research Perspectives. The ESPecialist, São Paulo, v. 27, n. 1, p. 83-118, 2006.

VELOSO, F. S; ALMEIDA, V. B. A fala facilitadora de dois interagentes no contexto de aprendizagem de LE no Teletandem. In: TELLES, J. A. (org.). Teletandem: Um contexto virtual, autônomo e colaborativo para a aprendizagem de línguas estrangeiras no século XXI. Campinas: Pontes, 2009. p. 149-168.

VYGOTSKY, L. S. Mind in Society: The Development of Higher Psychological Processes. Cambridge: Harvard University Press, 1978. 159p.

VYGOTSKY, L. S. The Genesis of Higher Mental Functions. In: WERTSCH, J. V. (ed.). The Concept of Activity in Soviet Psychology. Armonk: Sharpe, 1981. p. 144-188.

VYGOTSKY, L. S. Thought and Language. Cambridge: MIT Press, 1986. 287p. WARE, P. D. "Missed" Communication in Online Communication: Tensions in a German-American Telecollaboration. Language Learning \& Technology, Mānoa, Hawai, v. 9, n. 2, p. 64-89, 2005. DOI: https://doi. org/10.1111/j.1540-4781.2005.00274.x 
WARE, P. D.; KRAMSCH, C. Toward an Intercultural Stance: Teaching German and English Through Telecollaboration. The Modern Language Journal, [S.l.], v. 89, n. 2, p. 190-205, 2005. DOI: https://doi.org/10.1111/ j.1540-4781.2005.00274.x

WOOD, D.; BRUNER, J.; ROSS, G. The Role of Tutoring in Problem Solving. Journal of Child Psychology and Child Psychiatry, [S.l.], v. 17, p. 89-100, 1976. DOI: https://doi.org/10.1111/j.1469-7610.1976.tb00381.x

ZAKIR, M. A. Cultura e $(m)$ telecolaboração: uma análise de parcerias de teletandem institucional. 2015. 232f. Tese (Doutorado em Estudos Linguísticos) Programa de Pós-Graduação em Estudos Linguísticos, Universidade Estadual Paulista, São José do Rio Preto, 2015.

Data de submissão: 07/01//2020. Data de aprovação: 24/10/2020. 